\title{
Dentition and body condition: tooth wear as a correlate of weight loss in roe deer
}

\author{
Roberta Chirichella ${ }^{1 *} \mathbb{0}$, Anna Maria De Marinis² ${ }^{2}$ Boštjan Pokorny ${ }^{3,4}$ and Marco Apollonio ${ }^{1}$
}

\begin{abstract}
Background: In many mammalian species, once the permanent teeth have erupted, the only change to dentition is a gradual loss of tooth surface/height through wear. The crown of the teeth cannot be repaired once worn. When dental crown tissue has been depleted due to wear, the animal is expected to have a suboptimal body condition. We evaluated the role of tooth wear in causing a reduction of physical condition in adult roe deer females (Capreolus capreolus).

Results: The progressive wearing of the lower cheek teeth was assessed in a Northern Apennines (Italy) population with a new scoring scheme based on objectively described tooth characteristics (morphotypes) being either present or absent. Eviscerated body mass and mandible length, which is a good proxy for body size in roe deer, were related to the tooth wear score by the use of linear regressions. The sum of wear scores for molariform teeth correlated most strongly with body condition (i.e., eviscerated body mass/mandible length), showing the importance of the entire chewing surface for acquiring energy by food comminution, chewing, and digestion. In comparison with individuals of comparable size experiencing minor tooth wear, the body mass of those with the most advanced stage of tooth wear was decreased by $33.7 \%$. This method was compared to the height and the hypsodonty index of the first molar, the most commonly used indices of tooth wear. The sum of molariform wear scoring scheme resulted in a more suitable index to describe the variation in body condition of roe deer.

Conclusions: Describing tooth wear patterns in hunted populations and monitoring at which tooth wear level (and therefore dental morphotype) an animal is no longer able to sustain its physical condition (i.e. when it begins to lose body mass) can be a useful tool for improving the management of the most widespread and abundant deer species in Europe. At the same time, such an approach can clarify the role of tooth wear as a proximate cause of senescence in ungulates.
\end{abstract}

Keywords: Capreolus capreolus, Body mass, Cheek teeth, First molar height, Hypsodonty index, Scoring scheme, Tooth wear score, Senescence

\section{Background}

Senescence is defined as the gradual deterioration of function, accompanied by decreased survival and reproductive rates, with increasing age (e.g., $[1,2])$. The disposable soma hypothesis was, among others, proposed to

*Correspondence: rchirichella@uniss.it

${ }^{1}$ Department of Veterinary Medicine, University of Sassari, Via Vienna 2, 07100 Sassari, Italy

Full list of author information is available at the end of the article explain how senescence may evolve: it is based on optimal allocation of metabolic resources between somatic maintenance and reproduction [3]. Following this logic, all that is required is to keep the organism in sound condition for as long as it might survive in the wild $[4,5]$. The necessary amount of energy needed for this purpose in wild animals is strongly linked to foraging and mastication efficiency that is, in turn, related to physical efficiency: efficient teeth are, in mammals, a prerequisite for original author(s) and the source, provide a link to the Creative Commons licence, and indicate if changes were made. The images or other third party material in this article are included in the article's Creative Commons licence, unless indicated otherwise in a credit line to the material. If material is not included in the article's Creative Commons licence and your intended use is not permitted by statutory regulation or exceeds the permitted use, you will need to obtain permission directly from the copyright holder. To view a copy of this licence, visit http://creativecommons.org/licenses/by/4.0/. The Creative Commons Public Domain Dedication waiver (http://creativeco mmons.org/publicdomain/zero/1.0/) applies to the data made available in this article, unless otherwise stated in a credit line to the data. 
regularly acquiring and processing food both in carnivores and herbivores [6].

Mastication is of paramount importance in the digestive processes of mammalian herbivores [7-9]. Reducing particle size through chewing increases the surface area on which symbiotic microorganisms can act, thereby increasing the fermentation rate and cell wall degradation $[9,10]$.

Permanent teeth in many mammalian herbivores do not grow once fully emerged, and their crowns cannot be repaired when damaged or worn $[11,12]$. These types of teeth are used throughout an individual's lifetime to comminute food up to the point when their crowns are fully eroded. Thus, at the time of eruption, teeth already have all their potential lifetime investment in durability. The compensatory mechanism of adding cementum at the roots of the teeth, as demonstrated in some ruminants $[13,14]$, might only serve to delay but cannot prevent the loss of dental functionality associated with wear.

In ungulates, tooth wear has been suggested to be a proximal cause of senescence because it can negatively affect body condition and individual performance [ 1 , 2, 15-18]. Indeed, body condition and rates of survival and reproduction typically peak in prime-aged individuals in ungulates $[19,20]$. All these traits of performance have been reported to decrease with advanced age (see [19-21] for survival; [22] for reproduction; [23, 24] for body condition). However, only a few studies have tried to quantify the pattern of wear for the molariform teeth using objectively described characteristics and, as far as we know, the relationship between wear in molariform teeth and body condition has not been investigated. According to the available literature, tooth wear was compared either between captive and free-ranging ungulates [25], among populations living in different climatic/ environmental conditions [26-28] or having different diets [26, 27], showing more or less marked differences. The height of the first molar $\left(\mathrm{M}_{1}\right)$ and the hypsodonty index applied to molars have been the most widelyused indices of tooth wear [1,16, 29-31]. Subsequently, a description of the macroscopic effect of tooth wear by means of the mesowear method was introduced by [32] and [33], and has been applied to a very large number of extant and fossil species to infer a herbivorous diet. This method is based on the macroscopic observation of molar cusps that are worn by attrition, which is produced by one tooth occluding with its opposing tooth, and abrasion, which is caused by grinding food between teeth [34]. Recently, the mesowear method has undergone multiple applications, adaptations, simplifications, and extensions since its establishment [35]. However, in wildlife contexts this method cannot be experimentally applied as in domestic contexts [36-38].
Our study focuses on roe deer (Capreolus capreolus), the most widespread and abundant deer species in Europe, and a highly valued game species for which monitoring of population status is often required [39]. It is a relatively small ruminant [40] and, with its viscous saliva and unstratified rumen content, is generally classified as a strict browser along the browser-grazer continuum [41, 42]. However, its diet frequently contains $\geq 25 \%$ grass [43]. Considering that the wear pattern may vary according to the species, a scoring scheme was specifically developed for roe deer [44]. However, the wear process has not been studied in detail because ageing was the main aim of this research.

Our study aimed to: (1) propose a new tooth wear scoring scheme, describing the progressive wear of the cheek teeth based on objectively described characteristics being either present or absent; (2) determine if there is any evidence for a relationship between adult female body condition and the degree of tooth wear; (3) thus provide evidence of the role of tooth wear as a proximate cause of senescence determined as body weight loss in relation to animal (skeletal) size and select the best proxy of senescence using either tooth wear scores or the most widelyused indices of wear (i.e., the height of the first lower molar and the hypsodonty index).

In this context, describing the tooth wear pattern within a single population (i.e., a wild population with an uniform management regime and experiencing similar climatic/environmental conditions) and checking at which tooth wear level an animal is no longer able to sustain its optimal physical condition (i.e., when it begins to lose body mass till to reach values below the population average) can also facilitate comparisons of the lifehistory parameters of different populations that may live under varying environmental conditions (see [45]), and to understand the differential trends among them. This is especially important for income breeders such as roe deer [46], where females rely on food intake rather than fat reserves for reproduction [47]. Indeed, the income breeding strategy and the high level of maternal care in roe deer (e.g., [46]) increase the importance of being efficient enough to acquire energy throughout food comminution, chewing, and digestion not only for the survival of an individual mother but also for the long-term existence of viable populations.

\section{Methods \\ Study area}

The study was carried out in the Arezzo province (Tuscany, Central Italy, $43^{\circ} 28^{\prime} \mathrm{N}, 11^{\circ} 53^{\prime} \mathrm{E}$; Fig. 1). Approximately $57 \%$ of the territory is over $400 \mathrm{~m}$ above sea level (a.s.l.), with $7.4 \%$ of it being over $1000 \mathrm{~m}$ a.s.l. The climate 


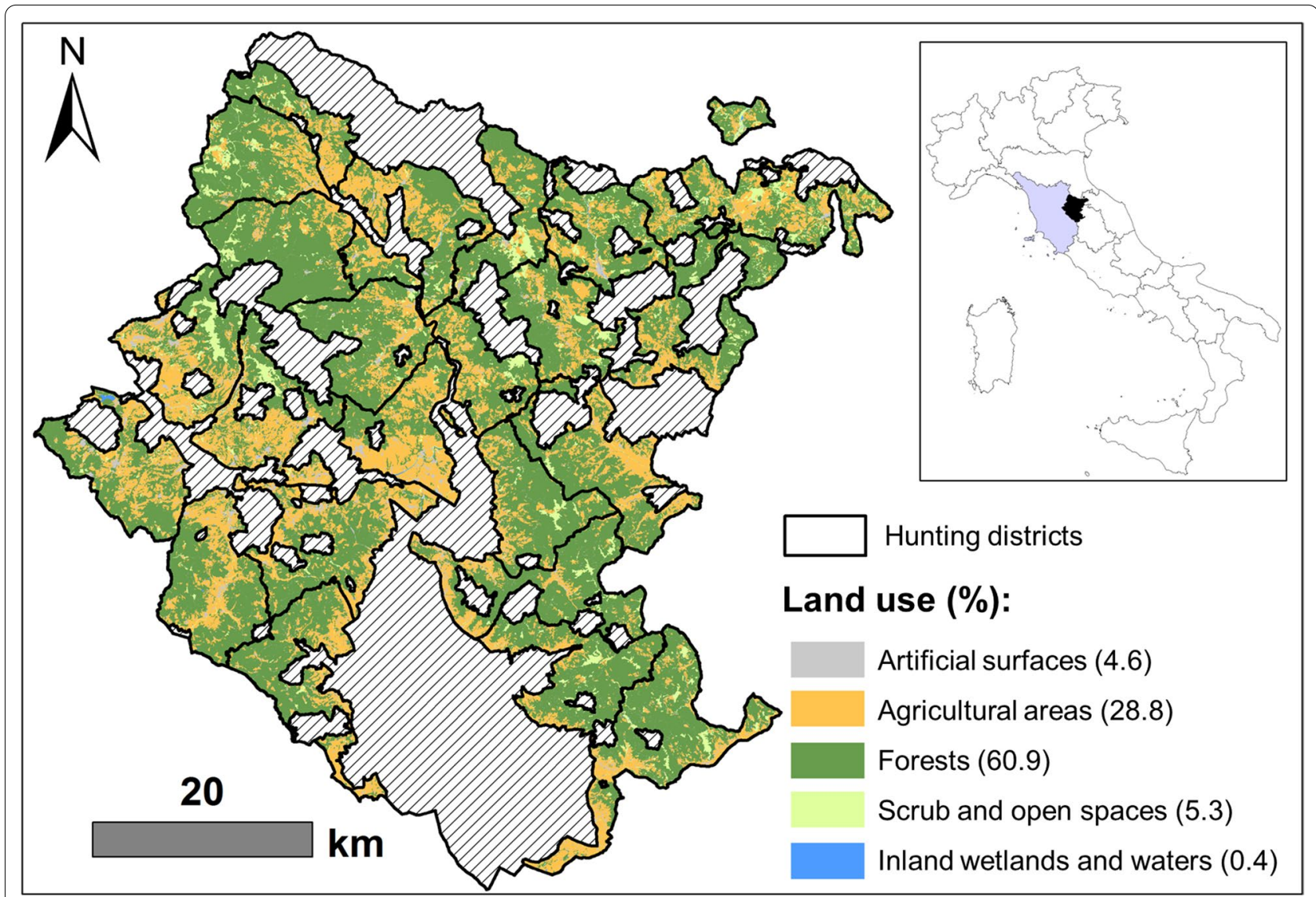

Fig. 1 Study area. Map of the study site located in the Arezzo province ( $43^{\circ} 28^{\prime} \mathrm{N}, 11^{\circ} 53^{\prime} \mathrm{E}$; black in the right panel), Tuscany (grey in the right panel), Central Italy. Study area includes 22 hunting districts (here classified into five land use classes according to Corine Land Cover 2012 , left panel) where 319 roe deer females were legally shot during the regular annual harvest (1 Jan-15 Mar for females) between 2007 and 2017. Percentage of each land use class is reported

is temperate continental, with a mean temperature ranging from $1.4{ }^{\circ} \mathrm{C}$ in January to $24.9^{\circ} \mathrm{C}$ in July.

Roe deer hunting is only allowed in hunting districts: in the Arezzo province, there are 22 hunting districts of about 9500 ha each, subdivided into hunting zones of 109.35 ha $\pm 1.22 \mathrm{SD}$. The hunting districts are evenly distributed throughout the province and cover an overall area of 114,000 ha. The majority (61\%) of this area is forested, predominantly composed of deciduous oaks (Quercus cerris and Q. pubescens) along with beech (Fagus sylvatica) and sweet chestnut (Castanea sativa). The remaining area consists of cultivated fields (29\%) and scrub or herbaceous vegetation (5\%) (see Fig. 1).

The study area harbors a rich wild ungulate community: besides roe deer, which is present in all the hunting districts, there are wild boar (Sus scrofa), fallow deer (Dama dama), red deer (Cervus elaphus), and mouflon (Ovis gmelini musimon). Wild boar is homogeneously distributed across the whole province, whereas red deer, fallow deer and mouflon are more localized [48]. The main predators are wolf (Canis lupus), with an estimated 25 packs, and red fox (Vulpes vulpes) $[49,50]$.

\section{Data collection}

In all 22 hunting districts of the Arezzo province, roe deer females are legally hunted each year from January $1^{\text {st }}$ to March $15^{\text {th }}$. Hunters prepared all the mandibles of hunted individuals through hot water maceration method, hand removal of soft tissue and cartilage, and 35\% hydrogen peroxide treatment. Each mandible was registered by the Provincial Government and made available to us for age assessment made by macroscopic inspection of teeth development and tooth wear [51], measurements and analyses. Age was determined using a tooth wear table developed locally, and validated age by histological examination of teeth through counting annual cementum layers in a sample set of $>300$ individuals from a previous data collection [52]. However, because this method provides uncertain assessment of age of adult roe deer [53], we grouped animals into the age groups that have been 
commonly used in previous roe deer studies (e.g. [54, 55]): fawns and yearlings/subadults $(<20-22$ months old; $\%$ available mandibles: $38 \%$ ), 2-year-olds (32-34 months old; $25 \%$ ), young adults (3-4 year; $25 \%$ ), middle-aged adults (5-7 year; $8 \%$ ), and old adults ( $\geq 8$ year; $3 \%$ ) (for major details about age estimation, see [55]). After regular annual evaluation, mandibles were stored according to the age class to which they belong and a sample of 319 roe deer mandibles was collected from adult females (i.e., older than 2 years) within the hunting season between 2007 and 2017 following the percentage of available mandibles in each age class. Only intact mandibles with intact teeth (i.e., not broken or chipped) were considered. Date of culling, sex, body mass (weight; BW), and hunting district were recorded for each roe deer. BW used in this study is eviscerated body mass (i.e., weighed without viscera and flowing blood). For the Arezzo province population, the mean eviscerated body mass of adult females culled in the Jan-Mar period was $18.1 \mathrm{~kg}$ [55].

In the laboratory, the length of the mandible $(\mathrm{ML} \pm 0.01 \mathrm{~mm})$ was measured as a proxy of skeletal size with a digital caliper. ML was measured (always by the same researcher) from the anterior margin of the alveolus of the first incisor $\left(\mathrm{I}_{1}\right)$ to the posterior margin of the Processus angularis (see [56]). For the Arezzo province population, the mean value of ML for adult females was $156.7 \mathrm{~mm}$ (see [56]).

The progressive wearing of the cheek teeth was assessed using a scoring scheme based on objectively described morphotypes being either present or absent. The scoring scheme for roe deer that we proposed and used is described in Table 1 . The proposed scoring scheme has been developed by AMDM and is based on 28 morphotypes recorded on two premolars $\left(\mathrm{P}_{3}\right.$ and $\left.\mathrm{P}_{4}\right)$ and all three molars $\left(M_{1}, M_{2}\right.$ and $\left.M_{3}\right) . P_{2}$ is the smallest premolar and has a simple crown in respect to other teeth that is only slowly changed by wear process $[57,58]$. Therefore, this tooth was not included in the scoring scheme as it does not provide any additional value to the description of the cheek teeth wear process. The wear process that affects each tooth of the molar arcade has been schematized in stages representative of the entire process and identifiable by dental morphotypes whose characteristics are easily recognizable [59]. The schematization was based on the shape of the occlusal surface. When molariform teeth are unworn, this surface is characterized by three valleys in premolars and cusps separated by deep infundibula in molars (Table 1; see [12, 25, 60-63] for nomenclature and terminology of morphotypes of the occlusal surface). The progressive wear of the crown determines the reduction in the number of valleys and the gradual fusion of the cusps and the disappearance of the infundibula (Table 1; see [12, 25, 60-63]). Taking this into account, the wear process has been outlined in stages, each of which is identified by a recognizable morphotype depending on the number of valleys for the premolars and the fusion of cusps for molars (see Table 1 for major details about the recognizable morphotypes). Morphotypes are, therefore, characters that can be uniquely identified by any observer.

Tooth wear was also estimated using height of the first molar $\left(\mathrm{M}_{1}\right)$ and the $\mathrm{M}_{1}$ hypsodonty index, which are the most widely-used indices of wear $[1,16,30,31]$. In cervids, it has been noted that although crown formation in $M_{1}$ is fully completed in the first months of life [64], the completion of eruption and final positioning of the molar in the mandible take place later [45, 64], and teeth also move in the mandible at very old age. Consequently, measuring molar height perpendicular from the mandible bone, labial or buccal side, is not necessarily a reliable measurement of molar wear [65]. Thus, the height $\left(\mathrm{HM}_{1} \pm 0.01 \mathrm{~mm}\right)$ of $\mathrm{M}_{1}$ was measured with a digital caliper as the distance from the peak of the mesiobuccal cusp to the enamel/cementum line (i.e., the stained part of the crown; see Fig. 2). The width ( $\left.\mathrm{WM}_{1} \pm 0.01 \mathrm{~mm}\right)$ of $\mathrm{M}_{1}$ was also measured with a digital caliper as the buccolingual breadth of the of the mesial cusp $[66,67]$. Both $\mathrm{HM}_{1}$ and $\mathrm{WM}_{1}$ were measured 3 times per each female and mean values were derived $\left(\overline{H M_{1}}\right.$ and $\left.\overline{W M_{1}}\right)$. Hypsodonty index (HI), defined as the height of $\mathrm{M}_{1}$ divided by the buccolingual breadth $[66,67]$, was calculated.

The dataset is available as Additional file 1.

\section{Data analyses}

Eviscerated body mass and ratio of eviscerated body mass to total mandible length (i.e., BW/ML), as a proxy of body condition in roe deer [68-70], were related to the tooth wear score in 319 roe deer adult females, and compared to the mean value of eviscerated body mass and the body condition index for adult females of the same population $[55,56]$.

Linear regressions were calculated between $\mathrm{BW}$ and $B W / M L$ (dependent variables) and (1) the wear scores of each tooth, (2) the sum of the scores obtained by pooling the molariform teeth in different ways (see Table 2 for the complete list of independent variables), (3) the height of $\mathrm{M}_{1}\left(\overline{\mathrm{HM}_{1}}\right)$, and (4) the hypsodonty index of $\mathrm{M}_{1}$. Models were compared by means of Akaike's Information Criterion for small sample sizes (AICc; [71]). Differences in body mass, mandible length and body condition index were investigated by ANOVA and Tukey HSD post hoc test for consecutive classes of tooth wear score (5 classes). The percentage of weight and body condition loss in relation to increasing tooth wear was calculated.

Statistical analyses were performed in $\mathrm{R}$ version 4.0.4 (www.r-project.org, [72]). 
Table 1 Tooth wear scoring system

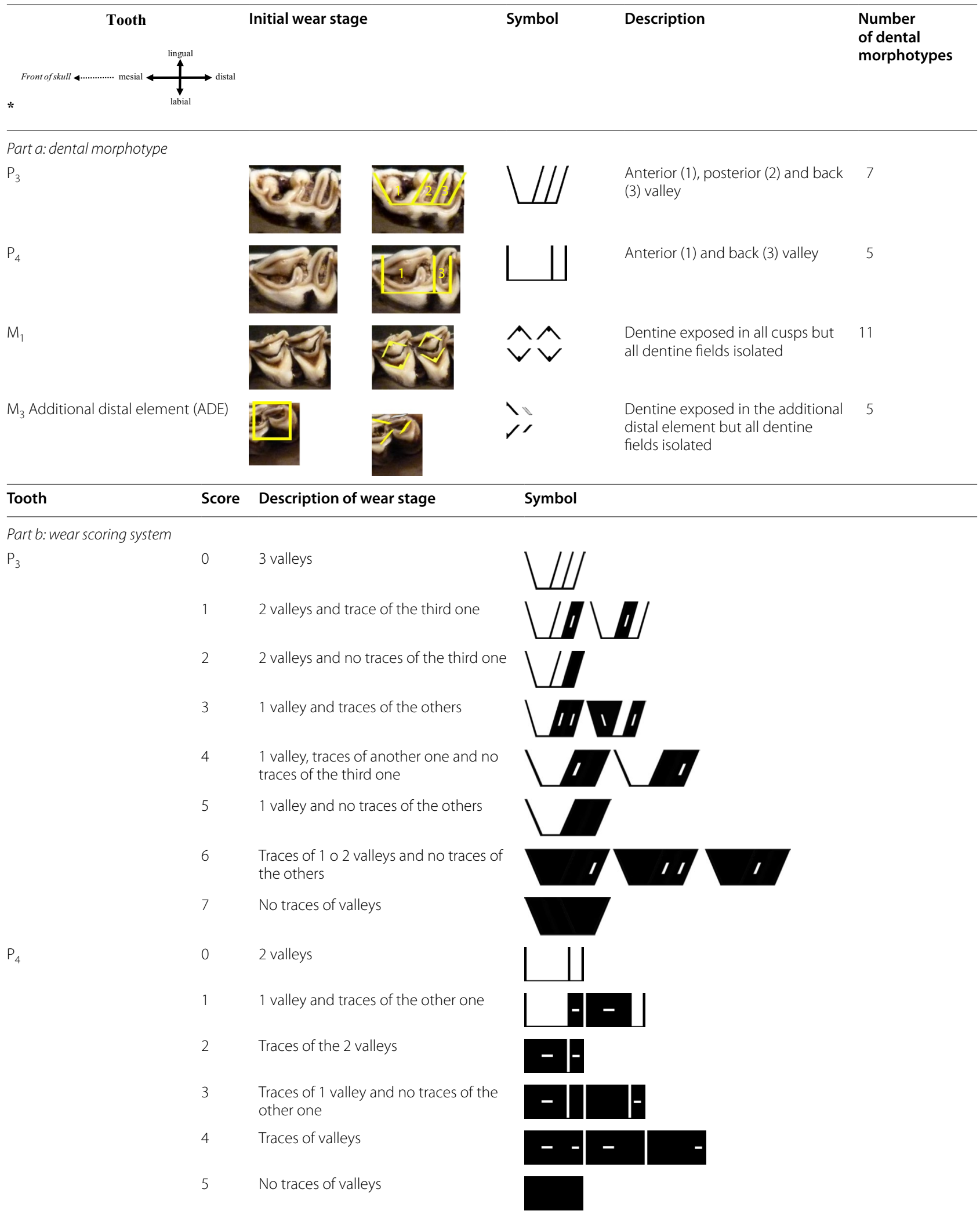


Table 1 (continued)

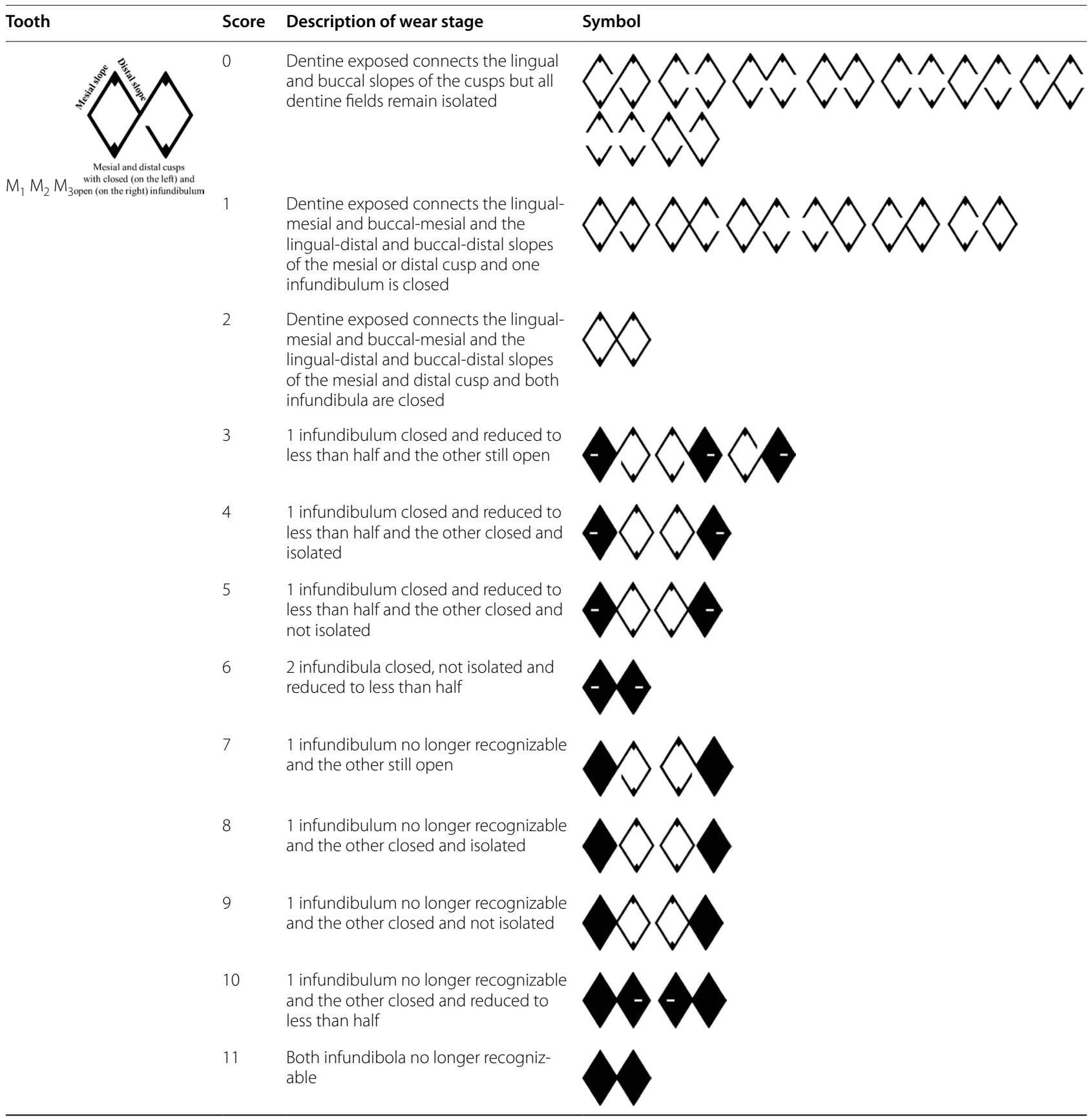


Table 1 (continued)

\begin{tabular}{|c|c|c|c|}
\hline Tooth & Score & Description of wear stage & Symbol \\
\hline \multirow[t]{6}{*}{$\begin{array}{l}M_{3} \text { Additional distal element } \\
\text { (ADE) }\end{array}$} & 0 & Not connected with other cusps & \\
\hline & 1 & $\begin{array}{l}\text { Dentine exposed connects respectively } \\
\text { buccal or lingual sides of the additional } \\
\text { distal element with the lingual-distal or } \\
\text { buccal-distal slopes of the distal cusps }\end{array}$ & \\
\hline & 2 & $\begin{array}{l}\text { Dentine exposed connects buccal and } \\
\text { lingual sides of the additional distal } \\
\text { element with the lingual-distal and } \\
\text { buccal-distal slopes of the distal cusps }\end{array}$ & \\
\hline & 3 & $\begin{array}{l}\text { Dentine exposed connects buccal and } \\
\text { lingual sides of the additional distal } \\
\text { element with the lingual-distal and } \\
\text { buccal-distal slopes of the distal cusps } \\
\text { with back fossa well visible }\end{array}$ & \\
\hline & 4 & $\begin{array}{l}\text { Dentine exposed connects buccal and } \\
\text { lingual sides of the additional distal } \\
\text { element with the lingual-distal and } \\
\text { buccal-distal slopes of the distal cusps } \\
\text { with traces of back fossa }\end{array}$ & \\
\hline & 5 & $\begin{array}{l}\text { Dentine exposed connects buccal and } \\
\text { lingual sides of the additional distal } \\
\text { element with the lingual-distal and } \\
\text { buccal-distal slopes of the distal cusps } \\
\text { with back fossa no longer recognizable }\end{array}$ & \\
\hline
\end{tabular}

*Surfaces of the teeth. Diagram showing the terminology used to designate the surfaces of the teeth toward and away from the mandibular symphysis (mesial and distal) and toward the lips and the tongue (labial and lingual)

Part a: Dental morphotype. Dental morphotypes are based on the shape of the occlusal surface changing in relation to the progressive wear patterns of each considered tooth. Morphotypes of the initial wear stage are described and represented through symbols. The number of dental morphotypes that schematize the entire wear process is reported for each molariform teeth. See Part b for a comprehensive description of each wear stage and score). See [12, 25, 60-63] for nomenclature and terminology of morphotypes of the occlusal surface

Part b: Wear scoring system. Scores assigned to the progressive wearing stages of the cheek teeth based on objectively described morphotypes being either present or absent in each tooth. The molariforms wear score is the sum of all individual scores (see [12, 25, 60-63] for nomenclature and terminology of the occlusal surface)

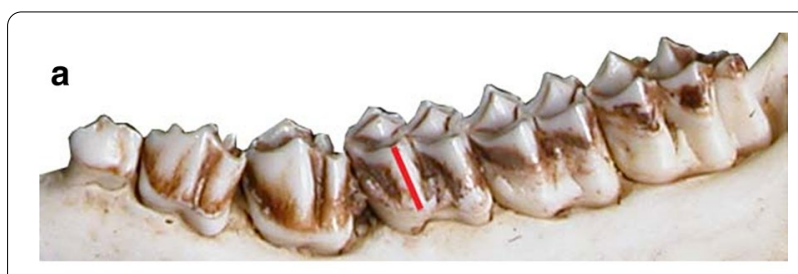

b

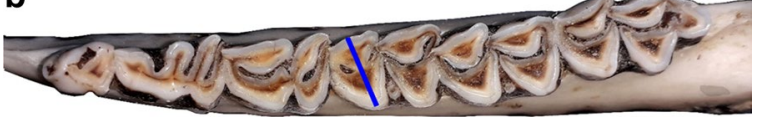

Fig. $2 M_{1}$ height and width. a Height of $M_{1}$ (red line) was measured with a digital caliper $\left(\mathrm{HM}_{1} \pm 0.01 \mathrm{~mm}\right)$ as the distance from the peak of the mesiobuccal cusp to the enamel/cementum line (i.e., the stained part of the crown). $\mathbf{b}$ Width of $\mathrm{M}_{1}$ (blue line) was measured with a digital caliper $\left(\mathrm{WM}_{1} \pm 0.01 \mathrm{~mm}\right)$ as the buccolingual breadth of the mesial cusp. Both $\mathrm{HM}_{1}$ and $\mathrm{WM}_{1}$ were measured 3 times per each female and mean values were derived $\left(\overline{H M_{1}}\right.$ and $\left.\overline{W M_{1}}\right)$

\section{Results}

Each evaluated proxy of weight and body condition loss showed a different ability to synthesize information for roe deer females (Table 2). Molars wear score $\left(M_{1}+M_{2}+M_{3 \text { total }}\right)$ and molariforms wear score $\left(\mathrm{P}_{3}+\mathrm{P}_{4}+\mathrm{M}_{1}+\mathrm{M}_{2}+\mathrm{M}_{3 \text { total }}\right)$, which will be referred to in all subsequent parts of the paper, were the best correlated with body mass (Table 2, Fig. 3). On the contrary, and $\mathrm{HI}$, despite their correlation with $\mathrm{M}_{1}$ wear score $\left(r_{p}=-0.67, p<0.001\right.$ for $\overline{H M 1}$ and $r_{p}=-0.65$, $p<0.001$ for HI; Fig. 4), were not suitable indices to describe the variation in body condition of roe deer (Table 2, Fig. 3).

Tooth wear score classes were related to significant loss of body mass and body condition (ANOVA: $\mathrm{F}_{4,314}=56.85, p<0.001$ for $\mathrm{BW} ; \mathrm{F}_{4,314}=47.57, p<0.001$ for BW/ML; for details, see Table 3 and Fig. 5), while no relation was found with mandible length $\left(\mathrm{F}_{4,314}=0.85\right.$, $p=0.49$; for details, see Table 3 and Fig. 5). Body mass 
Table 2 Relation between female roe deer body condition and tooth wear indices

\begin{tabular}{|c|c|c|c|c|c|c|c|c|}
\hline \multirow[t]{2}{*}{ Independent variables } & \multicolumn{4}{|l|}{ BW (kg) } & \multicolumn{4}{|l|}{ BW/ML (kg/mm) } \\
\hline & AICc (Rank, Value) & $R^{2}$ adj & $\mathbf{F}$ & $p$ & AICc (Rank, Value) & $R^{2}$ adj & $F$ & $p$ \\
\hline \multicolumn{9}{|l|}{ Tooth wear scores } \\
\hline$P_{3}$ & $7,1329.0$ & 0.221 & 91.26 & $<0.01$ & $7,-1838.6$ & 0.211 & 86.28 & $<0.01$ \\
\hline$P_{4}$ & $8,1331.7$ & 0.214 & 87.78 & $<0.01$ & $8,-1836.9$ & 0.210 & 85.60 & $<0.01$ \\
\hline$M_{1}$ & $9,1334.1$ & 0.209 & 84.80 & $<0.01$ & $9,-1830.1$ & 0.197 & 78.98 & $<0.01$ \\
\hline$M_{2}$ & $4,1296.9$ & 0.296 & 134.51 & $<0.01$ & $4,-1863.6$ & 0.281 & 125.47 & $<0.01$ \\
\hline$M_{3}$ & $5,1298.5$ & 0.292 & 132.22 & $<0.01$ & $5,-1859.9$ & 0.268 & 117.41 & $<0.01$ \\
\hline$M_{3 \text { (Additional Distal Element) }}$ & $10,1354.7$ & 0.156 & 59.65 & $<0.01$ & $10,-1821.0$ & 0.169 & 65.60 & $<0.01$ \\
\hline$M_{3 \text { total }}$ & $3,1279.4$ & 0.333 & 160.01 & $<0.01$ & $3,-1883.0$ & 0.324 & 153.44 & $<0.01$ \\
\hline Premolars $\left(P_{3}+P_{4}\right)$ & $6,1307.4$ & 0.272 & 119.89 & $<0.01$ & $6,-1858.5$ & 0.263 & 114.57 & $<0.01$ \\
\hline Molars $\left(M_{1}+M_{2}+M_{3 \text { total }}\right)$ & $2,1255.1$ & 0.382 & 197.64 & $<0.01$ & $2,-1899.5$ & 0.365 & 183.93 & $<0.01$ \\
\hline $\begin{array}{l}\text { Molariforms } \\
\left(P_{3}+P_{4}+M_{1}+M_{2}+M_{3 \text { total }}\right) \\
M_{1} \text { measurements }\end{array}$ & $1,1247.3$ & 0.397 & 210.48 & $<0.01$ & 1,-1907.6 & 0.381 & 196.48 & $<0.01$ \\
\hline$\overline{H M 1}$ & $11,1359.5$ & 0.145 & 55.13 & $<0.01$ & $11,-1806.2$ & 0.122 & 44.98 & $<0.01$ \\
\hline Hypsodonty index (HI) & $12,1364.5$ & 0.128 & 47.75 & $<0.01$ & $12,-1806.4$ & 0.120 & 44.48 & $<0.01$ \\
\hline
\end{tabular}

Main parameters of linear regressions between eviscerated body mass (BW in kg; on the left) and the ratio of eviscerated body mass to total mandible length (BW/ML in $\mathrm{kg} / \mathrm{mm}$; on the right) as a dependent variable and tooth wear scores, $M_{1}$ height $\left(\overline{H M_{1}}\right.$ in $\left.\mathrm{mm}\right)$ and hypsodonty index of $M_{1}(H I)$ for 319 roe deer females shot in the Arezzo province (Tuscany, Central Italy) during the regular annual harvest (1 Jan-15 Mar) between 2007 and 2017

and body condition decreased respectively by $33.7 \%$ and $30.8 \%$ in those with the most advanced stage of tooth wear compared to individuals experiencing minor tooth wear (Table 3). Eviscerated weight underwent a strong decrease when the molariforms wear score exceeded a value of 20. Individuals in the 21-30 wear score class had one or both infundibula closed in $\mathrm{M}_{1}$. With increasing wear score above this level, body masses were more and more frequently found to be below the population average $\left(R^{2}=0.50\right.$; see Fig. 6). This process was associated with the progressive disappearance of infundibula in $\mathrm{M}_{2}$ and $\mathrm{M}_{3}$.

\section{Discussion}

In roe deer, once the eruption process is completed, teeth undergo changes leading to a gradual loss of occlusal surface and a progressive decrease in crown height through a wearing process. Teeth cannot be repaired externally once worn $[11,12]$, despite a wear-compensation mechanism in dental roots confirmed in some ruminants (i.e., crown volume loss correlated to root volume gain; [13, 14]). These dental characteristics allowed us to test a new proposed tooth wear scoring scheme, describing the progressive wear of the cheek teeth.

The morphotypes described can represent the wear process, and the wear score classes identify stages that correspond to a progressive loss of dental functionality. This scoring system could give different results depending on the population because the turnover of morphotypes is obviously influenced by the characteristics of each individual as well as by the experiences and habits acquired in a specific type of environment [26-28]; with advancing age all this takes on greater importance, because the different ecological factors experienced by each individual accumulate over the years [59].

Our results clearly indicate that there is a relationship between adult female body condition and the degree of tooth wear. Moreover, the wear score of molariform teeth correlated the best with the body mass and body condition of adult females, showing the importance of the entire chewing surface in shaping the ability of the animal to acquire energy throughout food comminution, chewing, and digestion.

Many studies of wild ungulates have documented agerelated changes in adult body mass which may decline through senescence of physiological function and reduced foraging ability (reviewed in $[73,74]$ ) linked to advancing tooth wear (e.g., $[2,16])$. Indeed, tooth wear is a proxy of food intake investment that has been confirmed, for example, in red deer. In this species, stags with more worn teeth generally grow larger antlers for their age [75] and individuals of both sexes with more worn teeth have a larger skeletal body size for their age $[64,76]$. At the same time, because teeth in deer cannot be replaced or repaired during the animal's life, tooth wear becomes a proxy for animal lifespan $[2,18,64,65$, $75,77]$. Indeed, well-functioning molariform teeth are essential for digestive processes in ruminants, and their 

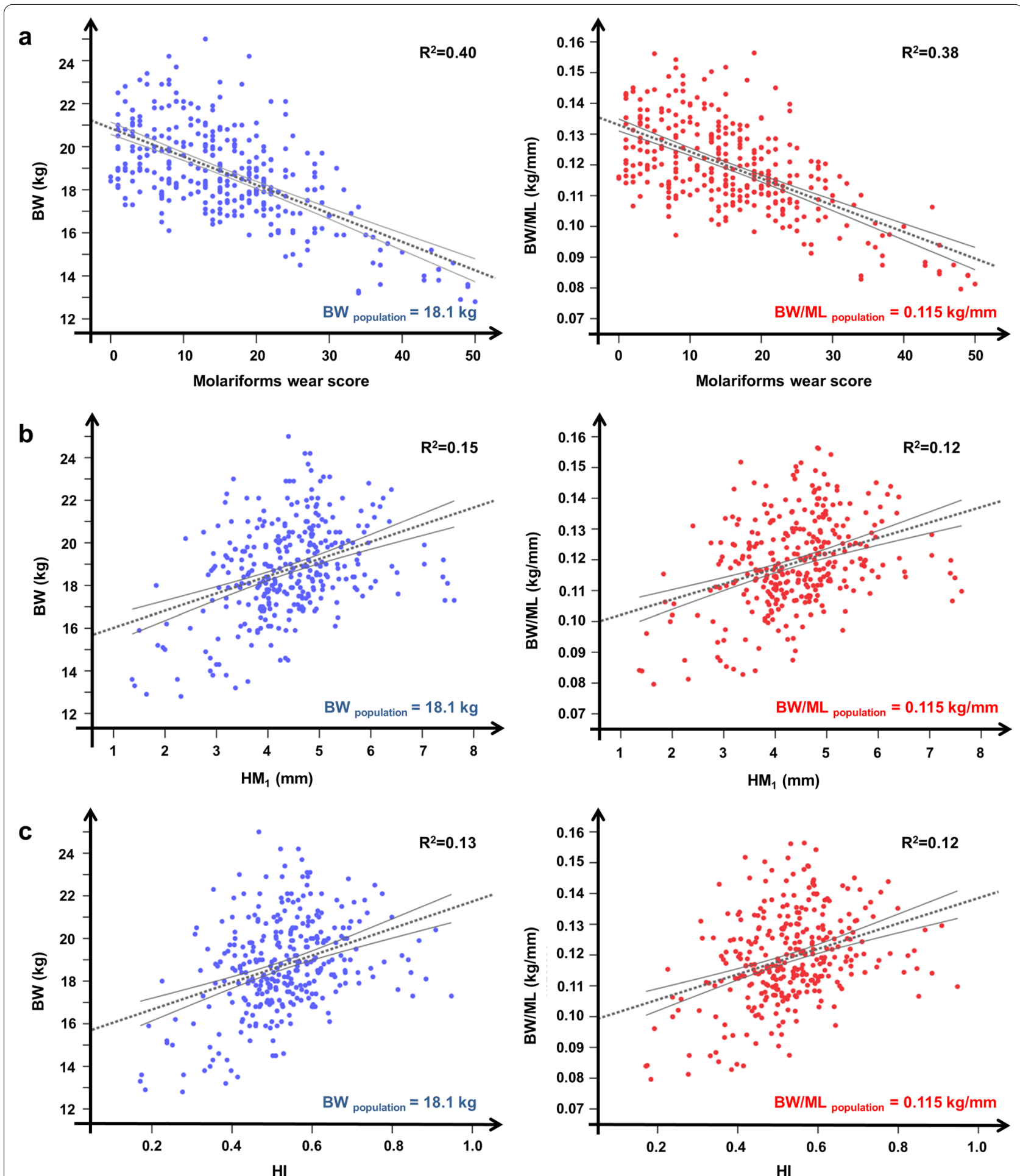

Fig. 3 Female roe deer body condition versus tooth wear indices. Eviscerated body mass (BW in kg; on the left) and the ratio of eviscerated body mass to total mandible length (BW/ML in $\mathrm{kg} / \mathrm{mm}$; on the right) as a dependent variable in relation to: $\mathbf{a}$ molariforms wear score, $\mathbf{b} \mathrm{M}_{1}$ height ( $\overline{\mathrm{HM}} \mathrm{M}_{1}$ in $\mathrm{mm}$ ), and $\mathbf{c}$ hypsodonty index of $\mathrm{M}_{1}\left(\mathrm{HI}\right.$ of $\mathrm{M}_{1}$ ) for 319 roe deer females shot in the Arezzo province (Tuscany, Central Italy) during the regular annual harvest (1 Jan-15 Mar) between 2007 and 2017. R of the linear regression (dotted grey line) is reported 

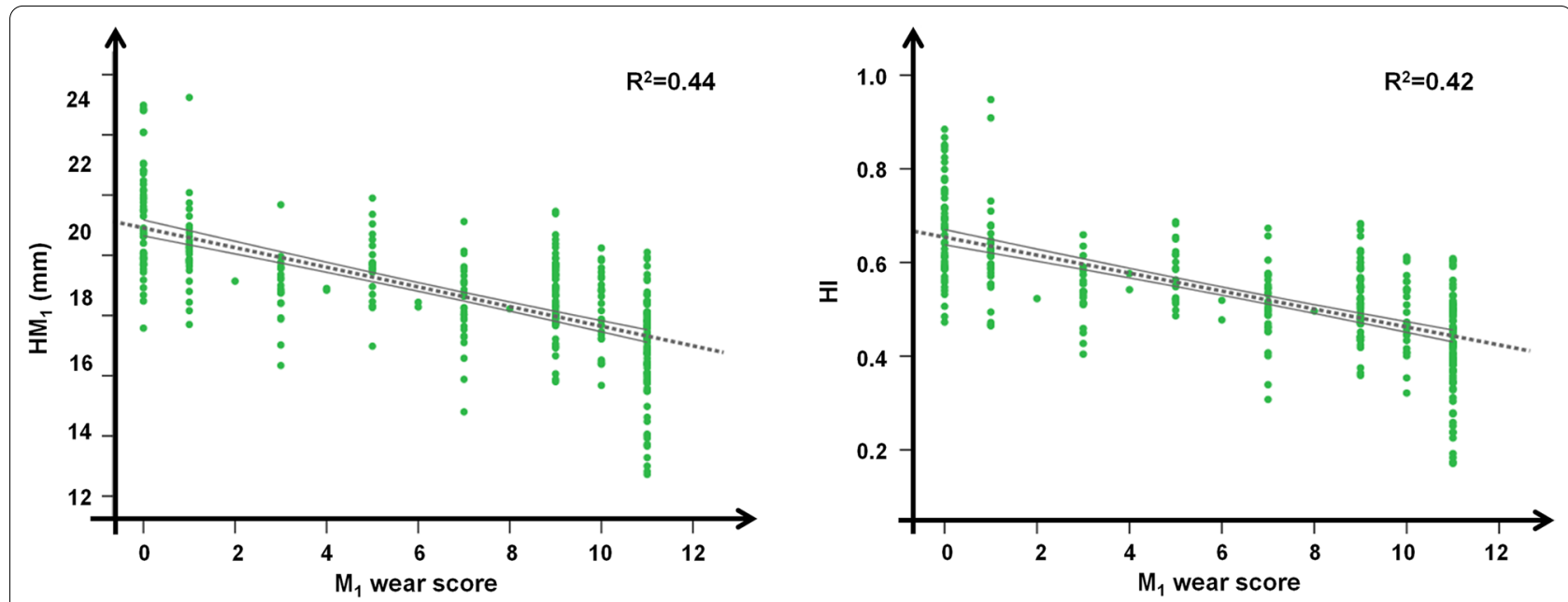

Fig. $4 M_{1}$ height and $M_{1}$ hypsodonty index versus $M_{1}$ wear score. Height $\left(H M_{1}\right)$ and hypsodonty index $(H I)$ of the first molar $\left(M_{1}\right)$ according to the increase in tooth wear score of $\mathrm{M}_{1}$ in 319 roe deer females shot in the Arezzo province (Tuscany, Central Italy) during the regular annual harvest (1 Jan-15 Mar) between 2007 and 2017. R² of the linear regression (dotted grey line) is reported

Table 3 Eviscerated body mass, mandible length and a body condition index in different classes of the molariforms tooth wear score

\begin{tabular}{|c|c|c|c|c|c|}
\hline & \multicolumn{5}{|c|}{ Tooth wear score classes } \\
\hline & achermagra? & 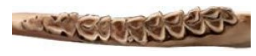 & 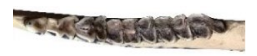 & 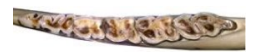 & 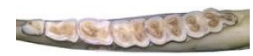 \\
\hline & $0-10(N=106)$ & $11-20(N=119)$ & $21-30(N=67)$ & $31-40(N=16)$ & $41-50(N=11)$ \\
\hline \multicolumn{6}{|c|}{ Eviscerated body mass (BW; kg) } \\
\hline Min & 16.1 & 15.9 & 14.5 & 13.2 & 12.8 \\
\hline Med & $19.9^{\mathrm{a}}$ & $19.1^{b}$ & $17.8^{c}$ & $15.6^{d}$ & $13.2^{e}$ \\
\hline Max & 24.2 & 25.0 & 22.1 & 19.0 & 15.2 \\
\hline$\%$ loss & - & 4.0 & 10.6 & 21.6 & 33.7 \\
\hline \multicolumn{6}{|c|}{ Mandible length (ML; mm) } \\
\hline Min & 142.97 & 147.23 & 146.39 & 151.07 & 143.02 \\
\hline Med & 157.21 & 157.77 & 157.63 & 158.86 & 159.23 \\
\hline Max & 167.91 & 167.43 & 166.56 & 168.24 & 167.53 \\
\hline$\%$ loss & - & - & - & - & - \\
\hline \multicolumn{6}{|c|}{ Body Condition Index (BW/ML; kg/mm) } \\
\hline Min & 0.10 & 0.10 & 0.09 & 0.08 & 0.08 \\
\hline Med & $0.13^{\mathrm{a}}$ & $0.12^{b}$ & $0.11^{c}$ & $0.10^{d}$ & $0.09^{e}$ \\
\hline Max & 0.16 & 0.16 & 0.15 & 0.12 & 0.11 \\
\hline$\%$ loss & - & 7.7 & 15.4 & 23.1 & 30.8 \\
\hline
\end{tabular}

Minimal, average and maximal values of eviscerated body mass (BW; $\mathrm{kg}$ ), mandible length ( $\mathrm{ML} ; \mathrm{mm}$ ) and a body condition index (BW/ML; $\mathrm{kg} / \mathrm{mm}$ ) of $319 \mathrm{roe}$ deer females shot in the Arezzo province (Tuscany, Central Italy) during the regular annual harvest (1 Jan-15 Mar) between 2007-2017 according to different classes of the molariforms' tooth wear score. Percentage of weight loss and body condition loss were calculated referring to individuals with minor tooth wear, i.e. those belonging to the score class $0-10$, and according to the differences in consecutive tooth wear score classes $\left(F_{4,314}=56.85, p<0.001\right.$ for BW; $F_{4.314}=47.57, p<0.001$ for BW/ $\mathrm{ML})$. Tukey HSD post hoc test results are indicated by superscripts (a-e) - means within a row not sharing the same superscript differ significantly. No differences in mandible length $\left(F_{4,314}=0.85, p=0.492\right)$ for consecutive tooth wear score classes were revealed. Pictures show the mean wear condition of each tooth wear class

functionality and durability are of major importance to animal performance. This is the case for many deer species (see [2, 18, 73, 78, 79] for red deer; [67] for sika deer (Cervus nippon); [1] for moose Alces alces; [16, 31] for reindeer Rangifer tarandus; [17] for roe deer). For example, in Slovenia roe deer females with the most advanced tooth wear (recognized as elderly individuals) 

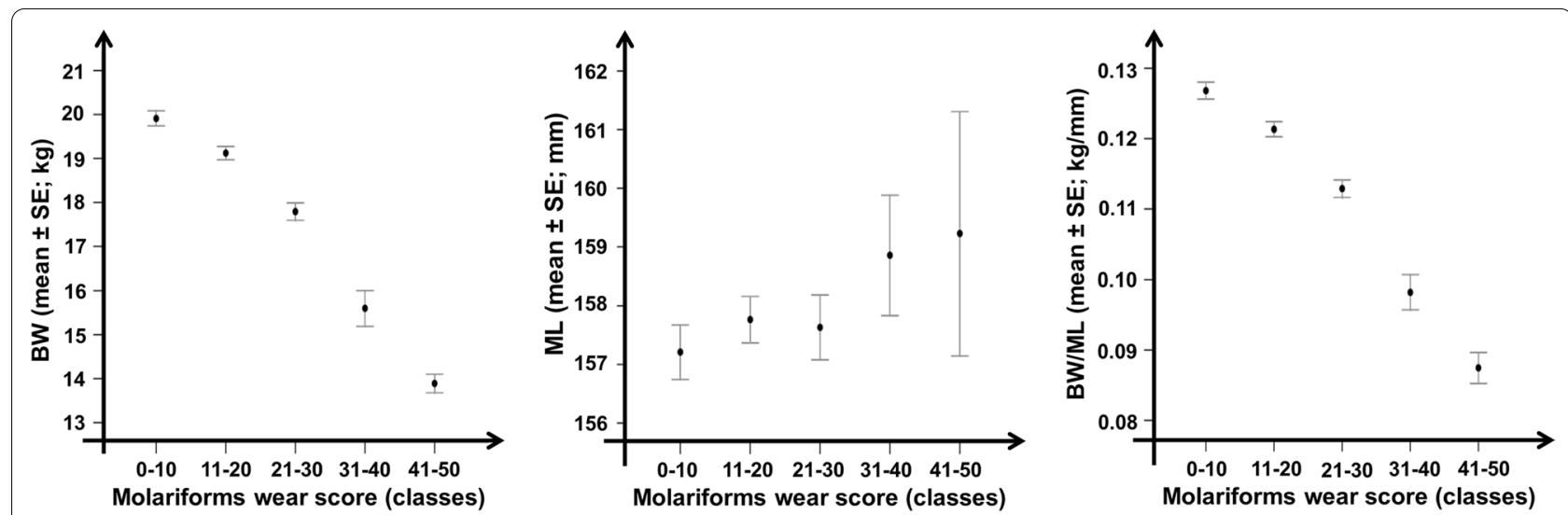

Fig. 5 Female roe deer body condition versus tooth wear score classes. Eviscerated body mass (mean \pm SE of BW in $\mathrm{kg}$; left panel), mandible length (mean \pm SE of ML in $\mathrm{mm}$; middle panel) and the ratio of eviscerated body mass to total mandible length (mean $\pm \mathrm{SE}$ of BW/ML in $\mathrm{kg} / \mathrm{mm}$; right panel) according to 5 tooth wear score classes for 319 roe deer females shot in the Arezzo province (Tuscany, Central Italy) during the regular annual harvest (1 Jan-15 Mar) between 2007 and 2017

on average weighed $1.7 \mathrm{~kg}(10.5 \%)$ less than females with moderate tooth wear [54].

Besides a significant influence on body mass, particularly in individuals with the most worn teeth as shown by our results (see Figs. 3, 6), reduced foraging ability due to advanced tooth wear may indirectly (via body mass related effects) influence some other life-history traits such as reproductive ability. In female ungulates, reproductive performance depends on a broad set of extrinsic and intrinsic factors (e.g. [80]). One of the most important factors is body condition, which depends, among other things, on individual history (i.e.

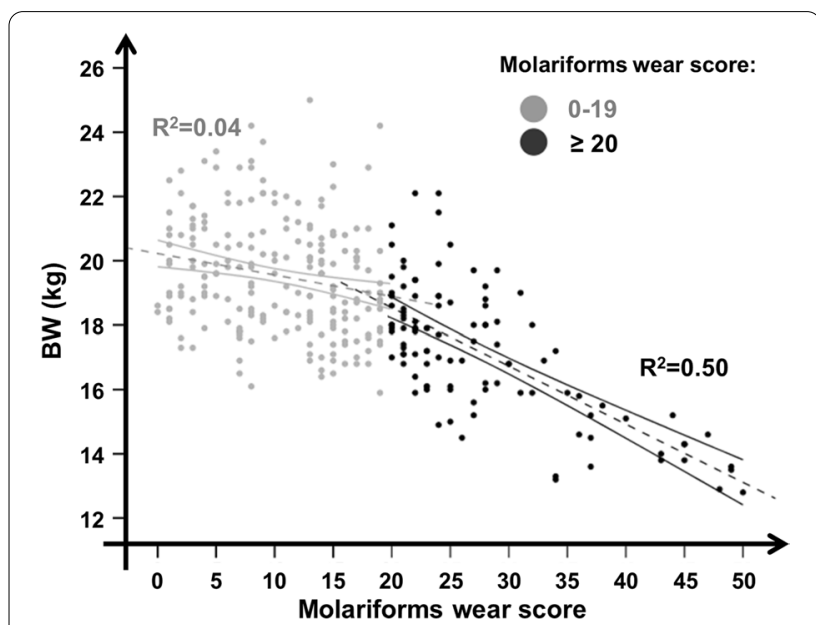

Fig. 6 Eviscerated body mass versus molariforms wear score. Eviscerated body mass (BW) according to the molariforms wear score in 319 roe deer females shot in the Arezzo province (Tuscany, Central Italy) during the regular annual harvest (1 Jan-15 Mar) between 2007 and 2017. $R^{2}$ of linear regressions are reported for females with a tooth wear score below (dot grey line) or above (dot black line) 20 age, reproductive history, and fertility; e.g. [81, 82]) and environmental-climatic conditions (i.e. habitat quality, weather conditions, and population density; e.g. $[83,84])$. Individual characteristics and food availability (quantity and quality) seem to be the most important factors because they shape how body reserves are invested, including in reproduction (e.g. $[85,86])$. As a consequence, reproductive success in female ungulates is strongly related to body mass in many species, such as wild boar Sus scrofa [87], caribou/reindeer [88], moose [89], and red deer [90].

In the case of our studied species, the roe deer, a pronounced influence of female body mass on reproductive success was clearly confirmed both within several European populations (reviewed in [91]) and among populations across Europe [92]. For example, in a similar environment to our study, [54] demonstrated that ovulation in roe deer females increases with higher body mass, while for our study area (Tuscany, Italy), [55] verified the important role of body mass in implantation success. These findings strongly confirm the pronounced influence of female body mass on reproductive success not only considering their potential at a very initial phase of reproduction (i.e. ovulation), but also when considering reproductive allocation in later and more costly phases (i.e. implantation). Furthermore, the positive effect of body mass on female reproductive performance, including implantation success, weakens with age, and aging strongly influences the overall reproductive performance of roe deer females. Lower ovulation ability in very old does [54], increases in implantation failure [55, 93, 94], and overall decrease in fertility and smaller litters with aging $[19,95]$ indicate the existence of reproductive senescence in roe deer females. As all these parameters of 
reproductive success are strongly related to female body mass (reviewed in [92]), our results suggest that reproductive senescence could be related to the reduced efficiency of teeth due to their excessive wear.

Finally, our study allowed us to compare our new tooth wear scoring scheme with the other widely-used indices of wear (i.e., the height and the hypsodonty index of $\mathrm{M}_{1}$ ). Both measurements are confirmed as indices that are able to provide general information on the wear pattern. However, they fail to synthesize the wear stages of the entire occlusal surface of the molar arcade and less correlate the variation in body conditions. These findings could be related to the high degree of wear of the first molar in the last years of life for deer species that doesn't allow much differentiation among individuals $[58,59]$.

Future work should aim to connect the true age of an individual with the tooth wear classes in order to verify when aging starts to be evident both through increases in tooth wear and decreases in body condition. This approach applied to populations of the same species living in different environments may help to elucidate intraspecies variability in population dynamics. Moreover, collecting longitudinal data with repeated tooth wear scoring in animals within the same population over longer timespan series (i.e., in different cohorts) may improve our ability to quantify the costs related to important life-history events such as reproduction, and to provide information about potential annual/periodic variation in tooth wear.

\section{Supplementary Information}

The online version contains supplementary material available at https://doi. org/10.1186/s12983-021-00433-w.

Additional file 1. Dataset. Individual characteristics, tooth wear scores, $M_{1}$ height and hypsodonty index of M1 data referred to 319 roe deer females legally shot during the regular annual harvest (1 Jan-15 Mar for females) between 2007 and 2017 in the Arezzo province (43 $\left.28^{\prime} \mathrm{N}, 11^{\circ} 53^{\prime} \mathrm{E}\right)$, Tuscany, Central Italy

\section{Acknowledgements}

We are grateful to the Arezzo province for supplying data. We are indebted to L. Mattioli and M. Meacci for their logistic support in collecting data. We would like to thank all the hunters who provided samples of roe deer mandibles, without which the study would not be possible. J. A. Nyakatura, M. Clauss, and an anonymous reviewer provided very helpful comments on earlier drafts of the manuscript. Mrs. Charlotte Taft revised the English language. B. Pokorny acknowledges the financial support of the Ministry of Agriculture, Forestry and Food of the Republic of Slovenia, and the Slovenian Research Agency (Project V1-2031; Program Group P4-0107), which will refund the open access publication fee.

\section{Authors' contributions}

AMDM, BP, MA and RC conceived and designed the study; AMDM developed the scoring system; AMDM and RC collected data; RC analysed data and wrote the first draft of the paper with the assistance of AMDM, BP and MA. All authors read and approved the final manuscript.

\section{Funding}

Ministry of Agriculture, Forestry and Food of the Republic of Slovenia, and the Slovenian Research Agency (Project V1-2031; Program Group P4-0107).

Availability of data and materials

All data generated or analysed during this study are included in this published article and its additional files.

\section{Declarations}

\section{Ethics approval and consent to participate}

The study complies with all relevant national, regional and provincial Italian laws and with the ethical standards of scholarly research.

\section{Consent for publication}

Not applicable.

\section{Competing interests}

The authors declare that they have no competing interests.

\section{Author details}

${ }^{1}$ Department of Veterinary Medicine, University of Sassari, Via Vienna 2. 07100 Sassari, Italy. ${ }^{2}$ Italian Institute for Environmental Protection and Research (ISPRA), Via Ca'Fornacetta 9, 40064 Ozzano dell'Emilia (BO), Italy. ${ }^{3}$ Environmental Protection College, Trg mladosti 7, 3320 Velenje, Slovenia. ${ }^{4}$ Slovenian Forestry Institute, Večna pot 2, 1000 Ljubljana, Slovenia.

Received: 30 April 2021 Accepted: 7 September 2021

Published online: 20 September 2021

\section{References}

1. Ericsson G, Wallin K. Age-specific moose (Alces alces) mortality in a predator-free environment: evidence for senescence in females. Ecoscience. 2001;8:157-63.

2. Carranza J, Alarcos S, Sanchez-Prieto CB, Valencia J, Mateos C. Disposablesoma senescence mediated by sexual selection in an ungulate. Nature. 2004:432:215-8.

3. Kirkwood TBL. The disposable soma theory: origins and evolution. In: Shefferson RP, Jones OR, Salguero-Gómez R, editors. The evolution of senescence in the tree of life. Cambridge: Cambridge University Press; 2017. p. 23-39.

4. Kirkwood TBL. Evolution of ageing. Nature. 1977:270:301-4.

5. Kirkwood TBL, Austad SN. Why do we age? Nature. 2000;408:233-8.

6. Sanson G. Cutting food in terrestrial carnivores and herbivores. Interface Focus. 2016;6(3):20150109.

7. Poppi DP, Norton BW, Minson DJ, Hendricksen RE. The validity of the critical size theory for particles leaving the rumen. J Agric Sci. 1980;94:275-80

8. Pond KR, Ellis WC, Akin DE. Ingestive mastication and fragmentation of forages. J Agric Sci. 1984;58:1567-74.

9. Pérez-Barbería FJ, Gordon IJ. Factors affecting food comminution during chewing in ruminants: a review. Biol J Linn Soc. 1998;63:233-56.

10. McArthur C, Sanson GD. Tooth wear in eastern grey kangaroos (Macropus giganteus) and western grey kangaroos (Macropus fuliginosus), and its potential influence on diet selection, digestion and population parameters. J Zool. 1988;215:491-504.

11. Lucas PW. Dental functional morphology. Cambridge: Cambridge University Press; 2004

12. Teeth HS. Cambridge manuals in archaeology. Cambridge: Cambridge University Press; 2005

13. Ackermans NL, Clauss M, Winkler DE, Schulz-Kornas E, Kaiser TM, Müller DWH, Kircher PR, Hummel J, Hatt J-M. Root growth compensates for molar wear in adult goats (Capra aegagrus hircus). J Exp Zool A. 2019;331:139-48.

14. Ackermans NL, Martin LF, Codron D, Kircher PR, Richter H, Clauss M, Hatt J-M. Confirmation of a wear-compensation mechanism in dental roots of ruminants. Anat Rec. 2021;304:425-36.

15. Tyler NJC. Natural limitation of the abundance of the high arctic Svalbard reindeer. Ph.D. dissertation, Cambridge: University of Cambridge; 1987. 
16. Skogland T. Tooth wear by food limitation and its life history consequences in wild reindeer. Oikos. 1988;51:238-42.

17. Gaillard JM, Delorme D, Boutin JM, Van Laere G, Pradel R. Roe deer survival patterns: a comparative analysis of contrasting populations. J Anim Ecol. 1993;62:778-91.

18. Loe LE, Mysterud A, Langvatn R, Stenseth NC. Decelerating and sex-dependent tooth wear in Norwegian red deer. Oecologia. 2003;135:346-53.

19. Gaillard JM, Festa-Bianchet M, Yoccoz NG. Population dynamics of large herbivores: variable recruitment with constant adult survival. Trends Ecol Evol. 1998;13:58-63.

20. Gaillard JM, Festa-Bianchet M, Delorme D, Jorgenson J. Body mass and individual fitness in female ungulates: bigger is not always better. Proc R Soc Lond. 2000;267:471-7.

21. Loison A, Festa-Bianchet M, Gaillard JM, Jorgenson JT, Jullien JM. Age-specific survival in five populations of ungulates: evidence of senescence. Ecology. 1999;80:2539-54.

22. McElligott AG, Altwegg R, Hayden TJ. Age-specific survival and reproductive probabilities: evidence for senescence in male fallow deer (Dama dama). Proc R Soc Lond. 2002;269:1129-37.

23. Mysterud A, Yoccoz NG, Stenseth NC, Langvatn R. The effects of age, sex and density on body weight of Norwegian red deer: evidence of density-dependent senescence. Proc R Soc Lond. 2001;268:911-9.

24. Yoccoz NG, Mysterud A, Langvatn R, Stenseth NC. Density-dependent and age related reproductive effort in male red deer. Proc $\mathrm{R}$ Soc Lond. 2002;269:1523-8.

25. Kaiser TM, Brasch J, Castell JC, Schulz E, Clauss M. Tooth wear in captive wild ruminant species differ from that of free-ranging conspecific. Mamm Biol. 2009;74:425-37.

26. Kaiser TM, Mueller DWH, Fortelius M, Schulz E, Codron D, Clauss M. Hypsodonty and tooth facet development in relation to diet and habitat in herbivorous ungulates: implications for understanding tooth wear. Mamm Rev. 2013;43:34-46.

27. Kubo MO, Takatsuki S. Geographical body size clines in sika deer: path analysis to discern amongst environmental influences. Evol Biol. 2015:42(1):115-27.

28. Kubo MO, Yamada E. The inter-relationship between dietary and environmental properties and tooth wear: comparisons of mesowear molar wear rate, and hypsodonty index of extant Sika deer populations. PLoS ONE. 2014;9(3):e90745.

29. Janis CM. An estimation of tooth volume and hypsodonty indices in ungulate mammals, and the correlation of these factors with dietary preference. In: Russell DE, Santoro JP, Sigogneau D, editors. Teeth revisited: proceedings of the VII international symposium on dental morphology. Paris: Muséum national d'Histoire naturalle du Paris; 1988. p. 367-87.

30. Fandos P, Orueta JF, Aranda Y. Tooth wear and its relation to kind of food: the repercussion on age criteria in Capra pyrenaica. Acta Theriol. 1993:38:93-102.

31. Kojola I, Helle T, Huhta E, Niva A. Foraging conditions, tooth wear and herbivore body reserves: a study of female reindeer. Oecologia. 1998;117:26-30.

32. Fortelius M, Solounias N. Functional characterization of ungulate molars using the abrasion-attrition wear gradient: a new method for reconstructing paleodiets. Am Mus Novit. 2000;3301:1-36.

33. Kaiser T, Solounias N, Fortelius M, Bernor RL, Schrenk F. Tooth mesowear analysis on Hippotherium primigenium from the Vallesian Dinotheriensande (Germany): a blind test study. Carolinea. 2000;58:103-14.

34. Fortelius M. Ungulate cheek teeth: developmental, functional, and evolutionary interrelations. Acta Zool Fenn. 1985;180:1-76.

35. Ackermans NL. The history of mesowear: a review. PeerJ. 2020;8:e8519.

36. Ackermans NL, Winkler DE, Schulz-Kornas E, Kaiser TM, Müller DWH, Kircher P, Hummel J, Clauss M, Hatt J-M. Controlled feeding experiments with diets of different abrasiveness reveal slow development of mesowear signal in goats (Capra aegagrus hircus). J Exp Biol. 2018;221:jeb186411.

37. Ackermans NL, Martin LF, Codron D, Hummel J, Kircher PR, Richter $H$, Kaiser TM, Clauss M, Hatt J-M. Mesowear resembles a lifetime signal in sheep (Ovis aries) within a long-term feeding experiment. Palaeogeogr Palaeoclimatol Palaeoecol. 2020;553:109793.
38. Stauffer JB, Clauss M, Müller DWH, Hatt J-M, Ackermans NL. Testing inner-mesowear III on goats (Capra aegagrus hircus) fed experimental diets. Ann Zool Fenn. 2019:56:85-91.

39. Apollonio M, Putman R, Andersen R. Ungulate management in Europe in the XXI century. Cambridge: Cambridge University Press; 2010.

40. Tixier H, Duncan P. Are European Roe Deer browsers? A review of variations in the composition of their diets. Revue d'Ecologie (Terre Vie). 1996;51:3-17.

41. Hofmann RR. Evolutionary steps of ecophysiological adaptation and diversification of ruminants: a comparative view of their digestive system. Oecologia. 1989;78:443-57.

42. Abbas F, Picot D, Merlet J, Cargnelutti B, Lourtet B, Angibault J-M, Daufresne T, Aulagnier S, Verheyden H. A typical browser, the roe deer, may consume substantial quantities of grasses in open landscapes. Eur J Wildl Res. 2013;59:69-75.

43. Spitzer R, Felton A, Landman M, Singh NJ, Widemo F, Cromsigt JP. Fifty years of European ungulate dietary studies: a synthesis. Oikos. 2020;129(11):1668-80.

44. Høye TT. Age determination in roe deer: a new approach to tooth wear evaluated on known age individuals. Acta Theriol. 2006;51:205-14.

45. Veiberg V, Loe LE, Mysterud A, Solberg EJ, Langvatn R, Stenseth NC. The ecology and evolution of tooth wear in red deer and moose. Oikos. 2007;116:1805-18.

46. Andersen R, Gaillard JM, Linnell JDC, Duncan P. Factors affecting maternal care in an income breeder, the European roe deer. J Anim Ecol. 2000;69(4):672-82.

47. Stephens PA, Boyd I, Mcnamara JM, Houston Al. Capital breeding and income breeding: their meaning, measurement, and worth. Ecology. 2009:90(8):2057-67.

48. Apollonio M, Mattioli L. II lupo in provincia di Arezzo. Montepulciano: Editrice Le Balze; 2006. ([in Italian]).

49. Bassi E, Donaggio E, Marcon A, Scandura M, Apollonio M. Trophic niche overlap and wild ungulate consumption by red fox and wolf in a mountain area in Italy. Mamm Biol. 2012;77:369-76.

50. Bassi E, Willis SG, Passilongo D, Mattioli L, Apollonio M. Predicting the spatial distribution of wolf (Canis lupus) breeding areas in a mountainous region of Central Italy. PLoS ONE. 2015;10(6):e0124698.

51. Ratcliffe PR, Mayle B. Roe deer biology and management. London: Forestry Commission Bulletin; 1992. p. 105.

52. Capitani C, Mattioli L, Apollonio M. Progetto di monitoraggio integrato degli ungulati nei distretti di gestione appenninici della Provincia di Arezzo. Arezzo: Technical Report [In Italian.] 2005. (in Italian).

53. Hewison AM, Vincent JP, Angibault JM, Delorme D, van Laere G, Gaillard $J M$. Tests of estimation of age from tooth wear on roe deer of known age: variation within and among populations. Can J Zool. 1999;77:58-67.

54. Flajšman K, Jerina K, Pokorny B. Age-related effects of body mass on fertility and litter size in roe deer. PLOS ONE. 2017;12(4):e0175579.

55. Chirichella R, Pokorny B, Bottero E, Flajšman K, Mattioli L, Apollonio $M$. Factors affecting implantation failure in roe deer. J Wildl Manag. 2019;83(3):599-609

56. De Marinis AM, Chirichella R, Bottero E, Apollonio M. Ecological conditions experienced by offspring during pregnancy and early post-natal life determine mandible size in roe deer. PLoS ONE. 2019;14(9):e0222150.

57. Barone R. Anatomia comparata dei mammiferi domestici. Osteologia, vol. 1. Bologna: Edizione Edagricole; 1995. ([in Italian]).

58. De Marinis AM, Toso S. Valutazione dell'età nei Cervidi tramite esame della dentatura. Manuali e Linee Guida n. 90. Roma: ISPRA; 2013. ([in Italian]).

59. De Marinis AM. Valutazione dell'età nei Cervidi tramite esame della dentatura. Guida pratica all'identificazione delle classi di età del Cervo. Manuali e Linee Guid n. 90.2. Roma: ISPRA; 2015. ([in Italian]).

60. Payne S. Kill-off patterns in sheep and goats: the mandibles from Asvan Kale. Anatol Stud. 1973;23:281-303.

61. Payne S. Reference codes for wear states in the mandibular cheek teeth of sheep and goats. J Archaeol Sci. 1987;14(6):609-14.

62. Bärmann EV, Rössner GE. Dental nomenclature in Ruminantia: towards a standard terminological framework. Mamm Biol. 2011;76:762-8.

63. Schultz JA, Menz U, Winkler DE, Schulz-Kornas E, Engels S, Kalthoff DC, von Koenigswald W, Ruf I, Kaiser TM, Kullmer O, Südekum KH. Modular wear facet nomenclature for mammalian post-canine dentitions. Hist Biol. 2018;30(1-2):30-41. 
64. Pérez-Barbería FJ, Duff El, Brewer MJ, Guinness FE. Evaluation of methods to age Scottish red deer (Cervus elaphus): the balance between accuracy and practicality. J Zool. 2014;294:180-9.

65. Pérez-Barbería FJ, Carranza J, Sánchez-Prieto C. Wear fast, die young: More worn teeth and shorter lives in Iberian compared to Scottish red deer. PLOS ONE. 2015;10(8):0134788.

66. Ozaki M, Suwa G, Kaji K, Ohba T, Hosoi E, Koizumi T, Takatsuki S. Correlations between feeding type and mandibular morphology in the sika deer. J Zool. 2007:272:244-57.

67. Ozaki M, Kaji K, Matsuda N, Ochiai K, Asada M, Ohba T, Hosoi E, Tado H, Koizumi T, Suwa G, Takatsuki S. The relationship between food habits, molar wear and life expectancy in wild sika deer populations. J Zool. 2010;280:202-12

68. Hewison AM, Vincent JP, Bideau E, Angibault JM, Putman RJ. Variation in cohort mandible size as an index of roe deer (Capreolus capreolus) densities and population trends. J Zool. 1996;239(3):573-81.

69. Blant M, Gaillard JM. Use of biometric body variables as indicators of roe deer (Capreolus capreolus) population density changes. Game Wildl Sci. 2004;21(1):21-40.

70. Hanzal V, Janiszewski P, Tajchman K, Košinová K. The correlation between mandibular length versus body mass and age in the European roe deer (Capreolus capreolus L.). Appl Ecol Env Res. 2017;15(4):1623-32.

71. Burnham KP, Anderson DR. Model selection and multimodel inference: a practical information-theoretic approach. 2nd ed. New York: Springer; 2002.

72. R Core Team. R: A language and environment for statistical computing. R Foundation for Statistical Computing, Vienna, Austria. 2020. https:// www.R-project.org/. Accessed 25 July 2021.

73. Nussey DH, Coulson T, Delorme D, Clutton-Brock TH, Pemberton JM, Festa-Bianchet M, Gaillard JM. Patterns of body mass senescence and selective disappearance differ among three species of free-living ungulates. Ecology. 2011;92(10):1936-47.

74. Nussey DH, Froy H, Lemaitre JF, Gaillard JM, Austad SN. Senescence in natural populations of animals: widespread evidence and its implications for bio-gerontology. Ageing Res Rev. 2013;12(1):214-25.

75. Carranza J, Mateos C, Alarcos S, Sanchez-Prieto CB, Valencia J. Sexspecific strategies of dentine depletion in red deer. Biol J Linn Soc. 2008:93:487-97

76. Pérez-Barbería FJ, Ramsay SL, Hooper RJ, Pérez-Fernández E, Robertson AHJ, Aldezabal A, Goddard P, Gordon IJ. The influence of habitat on body size and tooth wear in Scottish red deer (Cervus elaphus). Can J Zool. 2015:93:61-70.

77. Loe LE, Bonenfant C, Langvatn R, Mysterud A, Veiberg V, Stenseth NC. Increased effect of harsh climate in red deer with a poor set of teeth. Oecologia. 2006;147:24-30.

78. Nussey DH, Kruuk LE, Donald A, Fowlie M, Clutton-BrockTH. The rate of senescence in maternal performance increases with early-life fecundity in red deer. Ecol Lett. 2006;9(12):1342-50

79. Nussey DH, Metherell B, Moyes K, Donald A, Guinness FE, CluttonBrock TH. The relationship between tooth wear, habitat quality and late-life reproduction in a wild red deer population. J Anim Ecol. 2007;76(2):402-12.

80. Hamel S, Cote SD, Festa-Bianchet M. Maternal characteristics and environment affect the costs of reproduction in female mountain goats. Ecology. 2010;91:2034-43.
81. Del Giudice GD, Lenarz MS, Powell MC. Age-specific fertility and fecundity in northern free-ranging white-tailed deer: evidence for reproductive senescence? J Mammal. 2007;88:427-35.

82. Monteith KL, Stephenson TR, Bleich VC, Conner MM, Pierce BM, Bowyer RT. Risk-sensitive allocation in seasonal dynamics of fat and protein reserves in a long-lived mammal. J Anim Ecol. 2013;82:377-88.

83. Tavecchia G, Coulson T, Morgan BJT, Pemberton JM, Pilkington JC, Gulland FMD, Clutton-Brock TH. Predictors of reproductive cost in female Soay sheep. J Anim Ecol. 2005;74:201-13.

84. Simard MA, Coulson T, Gingras A, Cote SD. Influence of density and climate on population dynamics of large herbivores under harsh environmental conditions. J Wildl Manag. 2010;74:1671-85.

85. Therrien JF, Cote SD, Festa-Bianchet M, Ouellet JP. Maternal care in whitetailed deer; trade-off between maintenance and reproduction under food restriction. Anim Behav. 2008;75:235-43.

86. Cook RC, Cook JG, Vales DJ, Johnson BK, Mccorquodale SM, Shipley LA, Riggs RA, Irwin LL, Murphie SL, Murphie BL, Schoenecker KA, Geyer F, Hall BB, Spencer RD, Immell DA, Jackson DH, Tiller BL, Miller PJ, Schmitz L. Regional and seasonal patterns of nutritional condition and reproduction in elk. Wildl Monogr. 2013;184:1-44.

87. Fernández-Llario P, Mateos-Quesada P. Body size and reproductive parameters in the wild boar Sus scrofa. Acta Theriol. 1999;43:439-44.

88. Cameron RD, Smith WT, Fancy SG, Gerhart KL, White RG. Calving success of female caribou in relation to body weight. Can J Zool. 1993;71(3):480-6.

89. Testa JW, Adams GP. Body condition and adjustments to reproductive effort in female moose (Alces alces). J Mammal. 1998;79(4):1345-54.

90. Clutton-Brock TH, Albon SD, Guinness FE. Reproductive success in male and female red deer. In: Clutton-Brock TH, editor. Reproductive success. Studies of individual variation in contrasting breeding systems. Chicago: University of Chicago Press; 1988. p. 325-43.

91. Flajšman K, Jelenko I, Poličnik H, Pokorny B. Reproductive potential of roe deer (Capreolus capreolus L.): Review of the most important influential factors. Acta Silvae et Ligni. 2013;102:1-20.

92. Flajšman K, Borowik T, Pokorny B, Jędrzejewska B. Effects of population density and female body mass on litter size in European roe deer at a continental scale. Mammal Res. 2018;63:91-8.

93. Borg K. On mortality and reproduction of roe deer in Sweden during the period 1948-1969. Swed Wildl. 1970;7:121-49.

94. Hewison AM, Gaillard JM. Phenotypic quality and senescence affect different components of reproductive output in roe deer. J Anim Ecol. 2001;70:600-8.

95. Gaillard JM, Loison A, Toïgo C. Variation in life history traits and realistic population models for wildlife management. In: Festa-Bianchet M, ApolIonio M, editors. Animal behavior and wildlife conservation. Washington: Island Press; 2003. p. 115-32.

\section{Publisher's Note}

Springer Nature remains neutral with regard to jurisdictional claims in published maps and institutional affiliations.

Ready to submit your research? Choose BMC and benefit from

- fast, convenient online submission

- thorough peer review by experienced researchers in your field

- rapid publication on acceptance

- support for research data, including large and complex data types

- gold Open Access which fosters wider collaboration and increased citations

- maximum visibility for your research: over 100M website views per year

At $\mathrm{BMC}$, research is always in progress.

Learn more biomedcentral.com/submissions 